Article

\title{
Assessing the Sustainability of EU Timber Consumption Trends: Comparing Consumption Scenarios with a Safe Operating Space Scenario for Global and EU Timber Supply
}

\author{
Meghan O'Brien ${ }^{1,2, *}$ and Stefan Bringezu ${ }^{2}$ \\ 1 Wuppertal Institute for Climate, Environment and Energy, 42103 Wuppertal, Germany \\ 2 Center for Environmental Systems Research, University of Kassel, 34117 Kassel, Germany; \\ bringezu@uni-kassel.de \\ * Correspondence: meghan.obrien@wupperinst.org; Tel.: +49-202-2492-139
}

Received: 30 August 2017; Accepted: 21 November 2017; Published: 2 December 2017

\begin{abstract}
The growing demand for wood to meet EU renewable energy targets has increasingly come under scrutiny for potentially increasing EU import dependence and inducing land use change abroad, with associated impacts on the climate and biodiversity. This article builds on research accounting for levels of primary timber consumption-e.g., toward forest footprints-and developing reference values for benchmarking sustainability-e.g., toward land use targets-in order to improve systemic monitoring of timber and forest use. Specifically, it looks at future trends to assess how current EU policy may impact forests at an EU and global scale. Future demand scenarios are based on projections derived and adapted from the literature to depict developments under different scenario assumptions. Results reveal that by 2030, EU consumption levels on a per capita basis are estimated to be increasingly disproportionate compared to the rest of the world. EU consumption scenarios based on meeting around a $40 \%$ share of the EU renewable energy targets with timber would overshoot both the EU and global reference value range for sustainable supply capacities in 2030. Overall, findings support literature pointing to an increased risk of problem shifting relating to both how much and where timber needed for meeting renewable energy targets is sourced. It is argued that a sustainable level of timber consumption should be characterized by balance between supply (what the forest can provide on a sustainable basis) and demand (how much is used on a per capita basis, considering the concept of fair shares). To this end, future research should close data gaps, increase methodological robustness and address the socio-political legitimacy of the safe operating space concept towards targets in the future. A re-use of timber within the economy should be supported to increase supply options.
\end{abstract}

Keywords: global land use; sustainable production and consumption; sustainable forest management; footprints; European Union

\section{Introduction}

The EU Directive on the Promotion and the Use of Energy from Renewable Sources (RES Directive) mandates that Member States set legally binding targets for increasing the share of renewables in gross final consumption [1]. The EU target is $20 \%$ renewables by 2020. In 2012, the renewable share of energy comprised around $14 \%$, with wood contributing to more than $40 \%$ of renewable energy consumption in the EU-27 [2]. The RES Directive is expected to significantly increase the demand for fuelwood in the EU. However, such a substantial growth in timber consumption has increasingly come under scrutiny for potentially increasing environmental pressures domestically and abroad with harmful effects on e.g., the climate [3-5] and biodiversity [6,7]. 
For example, a large-scale strategy to increase bioenergy from forest harvest has been called into question: "This strategy is likely to miss its main objective to reduce GHG emissions because depleted soil fertility requires fertilization that would increase GHG emissions and because deterioration of current biomass pools requires decades to centuries to be paid back by fossil fuel substitution, if paid back at all." [3] (p. 5). The authors also argue that forest canopy structure and composition would be simplified, affecting ecosystem diversity, function and habitat (ibid).

Similar findings have been made at the EU level. A report from the Joint Research Centre of the European Commission assessed the current practice of carbon accounting for forest bioenergy. It argues that: "The assumption of biogenic carbon neutrality is not valid under policy relevant time horizons (in particular for dedicated harvest of stemwood for bioenergy only) if carbon stock changes in the forest are not accounted for" [5] (p. 18). The study recognizes that the classification of 'carbon neutrality' increases the attractiveness of using timber for renewable energy generation, and notes that stemwood harvesting for bioenergy purposes is expected to grow in the future. However, it finds that: "The use of stemwood from dedicated harvest for bioenergy would cause an actual increase in GHG emissions compared to those from fossil fuels in the short and medium term (decades), while it may start to generate GHG savings only in the long term (several decades to centuries)" [5] (p. 16). The study argues that a decrease in emissions due to removal of forest residues, thinning and salvage logging is more achievable in the short term, especially if the counterfactual scenario would be to burn the residues on the roadside. This feedstock is expected to provide most of the additional increment of biomass for bioenergy by 2020 according to that study (ibid).

However, the sustainable potential of forest residues estimated by the literature varies. At a global level more modest, yet realistic, estimates relate to around 4 EJ (Exajoule) to $6 \mathrm{EJ}\left(440 \mathrm{Mm}^{3}\right.$ to $660 \mathrm{Mm}^{3}$ ) [8,9]. This could cover only around $1 \%$ of current global primary energy demand, but would raise total harvest supply volume by around $11 \%$ to $16 \%$. However, these values seem relatively high in comparison to the $\mathrm{EU}$, where sustainable residue removal is estimated to increase the supply capacity of EU forests by around 10\% [10-13], or even only $5 \%$ in one scenario with stricter environmental regulations [14]. Even minor increases in harvesting and removing residues may cause major nutrient losses [15]. More research is urgently needed on the sustainable potential of residue removal—including stumps and roots [16,17]—for different types of forests. It does not, however, seem likely that the level of wood needed to meet renewable energy targets in the EU may be sourced from residues alone. This raises the questions: how should timber be sourced and can it be supplied in a sustainable way?

The European Forest Sector Outlook Study II reaches similar conclusions about the challenges of meeting renewable energy targets with wood [18]. The study suggests developing a strategy that integrates the needs of the energy sector with that of the forest sector by, e.g., promoting energy efficiency, cascading use, other renewables and non-forest sources of timber. It also suggests to: "Develop fast growing biomass plantations on agricultural land where this is possible [and] if necessary import energy wood (or fuels derived from wood such as pellets or biofuels, which are considerably more energy intensive) from sustainable sources outside Europe" [18] (p. 81). This raises concerns about the impacts of EU timber consumption in other regions as well as on the growing import dependence of the EU.

Looking at global trends, it is commonly assumed that industrial roundwood will increasingly come from planted forests in the future [19], and that: "Growth in production from planted forests is expected to keep up with [global] demand growth for industrial roundwood." [19] (p. 69). This trend raises concerns about sustainable land use. The concept of sustainable forest management has evolved from exploitive forestry-where the objective of sustainable forest management was to sustain yields-to precision forestry-where the objective of sustainable forest management is closer to integrated natural resource management [20,21]. Industrialized, fast-growing plantations are typically managed to only optimize timber productivity. On the one hand, fast-growing plantations need less total area to produce timber, and thus may free-up natural forests for other services [22], especially 
if those plantations are established and managed with community interests and landscape uses in mind $^{1}$ [23]. On the other hand, as land competition grows, fast-growing plantations managed exclusively for timber may increasingly compete for land with natural forests managed for multiple services. There is a risk that high yield timber production will gain the upper hand in this competition, because it is more profitable over the short term [24]. The demand for products from low-quality timber (e.g., pulp and wood-based panels) as well as fuelwood, are also increasing and are well-suited to fast-growing plantations. Through high-tech innovation, such wood fibre can be made into "new" types of products (e.g., including composite woods), changing the structure of the forest industry over the long term [25]. Demand for high-quality timber from a forest managed for multiple-uses may increase the value of that forest, and raise incentives to manage it in a sustainable way. While too high of a demand may cause overharvesting, too low of a demand may decrease the incentives to manage it in a sustainable way (especially if another kind of land use is more profitable). This points to the need for a combination of production and consumption oriented approaches to promote balance between sustainable forest management and sustainable timber consumption.

It is the level of demand that determines the magnitude of potential impacts. Certification can support sustainable management practices at the forest level but is ineffective against overexploitation caused by high levels of demand. For example, as a "thought experiment", if a country or territory like the EU were to substitute all fossil fuels used for heating with timber, all else being equal, most would intuitively agree that this would be unsustainable due to the high level of demand (regardless of site certification). Granted, this is an extremely far-fetched "scenario", but it does raise an important question: how much timber can be consumed under sustainable conditions, now and in the future? This article argues that a sustainable level of timber consumption is characterized by balance between supply (what the forest can provide on a sustainable basis) and demand (how much is used on a per capita basis, considering equity and the concept of "fair shares" [26,27]. This is easier to imagine at a local scale, with a visible link or feedback signal between supply and demand (e.g., causing the price to increase as the resource becomes more scarce and/or impacts emerge). Trade removes or delays the signal between the forest (costs of overharvesting) and economy. This removes incentives within society to adjust use patterns to new conditions (striving for more efficient use and re-use, changing wasteful behaviors, developing innovations, etc.). As such, nations need a reference for when their consumption levels have surpassed this balance. Such a reference value must take both ecological limits and global equity into account to reflect the goals of sustainable development. For example, already in 1992, Agenda 21 stated: "Special attention should be paid to the demand for natural resources generated by unsustainable consumption ... Although consumption patterns are very high in certain parts of the world, the basic consumer needs of a large section of humanity are not being met." Agenda 21 [28] implies that people in high consuming countries need to limit their total consumption to levels which allow others-at a bare minimum-to reach a basic quality of life. This includes consideration of other resource types. For example, growing timber in plantations (e.g., to fuel high and wasteful uses of energy in high income economies) using high amounts of fresh water in places where water is scarce and undernourishment is widespread would not contribute to overarching sustainable development goals.

In light of these concerns about (a) where the increasing demand for timber should be sourced, (b) how it should be grown, and (c) how much can be extracted within sustainability limits, a recent series of articles and publications argues for and makes the first steps toward developing the methodological basis for a systemic monitoring of EU timber and forest use [29-31]. The first article [30] developed an approach to account for primary timber flows of woody biomass in order to develop

1 E.g., The New Generation Plantations platform aims to promote establishment of forest plantations that contribute positively to local welfare and natural ecosystems: http:/ / newgenerationplantations.org. 
indicators of EU primary timber consumption (e.g., toward forest footprints ${ }^{2}$ ). Best estimates found that EU consumption was around 1.6 times higher than the global average on a per capita basis in 2010 . A second article [31] developed a reference value range for EU and global sustainable supply capacities as a benchmark for sustainable consumption levels. On a per capita basis, it was found that the EU has more capacity for sustainable supply than the global average, in particular due to relatively high amounts of forest available for wood supply in the EU with high productivities. Which benchmark (global and/or territorial) is appropriate as an orientation for EU policy making was discussed at length. In 2010, European consumption levels were below the most realistic estimates of EU sustainable supply capacities but exceeded global sustainable supply capacity estimates on a per capita basis by more than 50\% [29]. This article builds on both articles [30,31] in order to better understand how EU and global timber consumption trends may develop in the future, both in comparison to each other as well as to future reference value ranges for sustainable consumption.

In this way, this article aims to contribute to developing a systemic monitoring perspective that takes potential future impacts of current policy decisions into account. It also aims to stress the need for considering trends of both production and consumption in monitoring natural resource use. It should be emphasized that this is a first step toward further developing such a consumption-based perspective for better understanding of what it means to promote a sustainable level of timber consumption as part of a sustainable development transition. Goal 12 of the Sustainable Development Goals aims to promote responsible consumption and production, with the target of achieving sustainable management and efficient use of natural resources by $2030^{3}$. This article begins to look at the metrics to that end for timber and forests in more detail. In this sense, it uses and builds on available data and scenarios in a rather simplistic way to check first whether there is a problem and, upon highlighting risky trends, calls for much more robust methods and approaches to further develop a systemic monitoring system capable of providing strong policy recommendations.

This article begins with a literature review of timber consumption scenarios at the global and EU levels. These scenarios are the basis for checking whether future developments may stay within or exceed a potential sustainability corridor in the future. Results are presented and discussed, with future research needs emphasized. Conclusions summarize key findings and provide concise policy implications, in particular on the need for better monitoring.

\section{Scenarios of Timber Consumption}

\subsection{Global Scenarios}

Two key studies were reviewed and assessed for forecasting future timber demand at the global level $[19,35]$. In this article, the purpose of a review at the global level is to provide a context for European consumption developments and an overarching picture of how global development might compare to a future global reference value range for sustainable consumption (developed by $\mathrm{O}^{\prime} \mathrm{Brien}$ and Bringezu [31]). The first study [35] uses the Global Forest Products Model (GFPM) to make projections about the future consumption of forest products as well as the impact on the forest area and forest stock until 2060. The GFPM is a dynamic economic model of 14 forestry commodity groups in the world economy linked to forest stock (volume) on a changing forest area according to the Kuznets curve (linking forest area growth with income prosperity). It calculates the final

2 Footprints describe a consumption-oriented approach for monitoring environmental pressures. The four footprints-materials, water, carbon and land-are gaining increasing attention at both the European and international levels [7,32,33], although the methodological robustness and level of calculation differs widely among all categories [34]. The initial and rough footprint methodology for forestry applied by [30] is based on accounting for removals plus imports minus exports. Trade data are converted to primary timber equivalents through conversion values and all secondary flows reported by the data were removed. They are reported in cubic meters per capita and refer to primary raw timber demand (e.g., woody biomass from forest areas, excluding recycled and reused sources).

3 See the website of the United Nations: https:/ / sustainabledevelopment.un.org/?menu=1300. 
demand and raw materials supply in world equilibrium according to econometric equations, with the price elasticity of supply of fuelwood and industrial roundwood the same in all countries (e.g., 1.31) except the United States (where it was exogenous according to the United States Forest Products Module). Buongiorno, et al. [35] use the IPCC scenarios A1B (continuing globalization, high income growth, low population growth and a 5.5 times increase in biofuels demand), A2 (slowdown of globalization, lower income and higher population growth with a 2.7 times growth in biofuel demand) and B2 (with medium projections) to set the context for projecting timber demand. It should be noted that strong assumptions and critical uncertainties (e.g., related to demand elasticities, forest growth parameters, and exogenous factors connected to the IPCC scenarios, in particular as regards biofuels growth) warrant applying due caution [36] in interpreting these, as well as all scenarios presented.

The second study [19] is from the FAO and forecasts global timber demand for world regions until 2030. It uses, for example, forest sector outlook studies (performed together with the FAO and regional experts) to present trends in different regions of the world. At the aggregated global level, FAO derives the demand for industrial roundwood from expected growth in end products (sawnwood, wood-based panels and paper and paperboard). It forecasts a more than doubling in demand for wood-based panels and paper and paperboard between 2005 and 2030 and a 50\% increase in the demand for sawnwood. In particular, demand in Asia is expected to increase significantly. The report [19] assumes that recycled materials and wood residues will comprise a growing share of supply for these end products in 2030 (50\%, up from 30\% in 2005) in particular because of expected rates of paper recycling in the future, lowering the demand for primary timber. While total wood and recycled fibre demand for products is projected to almost double, the demand for industrial roundwood is expected to increase by around 40\% between 2005 and 2030. For fuelwood, report [19] uses interpolation from trends and projections for biomass energy production from the International Energy Agency (IEA) and the Food and Agricultural Organization of the United Nations (FAO) to suggest that wood used for bioenergy production increased from around $2 \mathrm{Gm}^{3}$ in 1970 to $2.6 \mathrm{Gm}^{3}$ in 2005 and will reach $3.8 \mathrm{Gm}^{3}$ by 2030 (noting that some of this demand could be satisfied by biomass produced from agricultural residues and energy crops).

\subsection{EU Scenarios}

Literature in the EU has focused on forecasting future demands for both products and fuelwood. For example, one study [37] performed econometric modeling to project wood product demand, supply and trade in Europe until 2030. The study applied a multiple equations approach with data stemming from FAOSTAT, UNECE, UN Comtrade, FAO [19], and the EFORWOOD project and, like Buongiorno, et al. [35], used the IPCC scenarios A1 and B2 to reflect possible variations of the market context. Results shows that the consumption of wood products is expected to increase in both future scenarios, with an increase in consumption growth in the A1 scenario and a slow down in the B1 scenario. In both scenarios, consumption growth for paper decreases, potentially due to progress in technology. In comparison to consumption, European production is in general projected to outgrow consumption in both scenarios, increasing the self-sufficiency rate as regards industrial products. According to the study [37], the most significant development in Western Europe (EU-15) until 2030 is the shift from substantial net importer to a small net exporter of solid wood products.

Another report [38] estimated the amount of timber needed to meet the Renewable Energy (RES) Directive in 2020 and 2030. In the scenario presented, it is assumed that energy efficiency gains of around $20 \%$ would decrease gross inland energy consumption demand to $61.6 \mathrm{EJ}$ in 2020 and $51.8 \mathrm{EJ}$ in 2030, meaning that renewables would need to cover 12.2 EJ in 2020 and 16 EJ in 2030 [38]. The share of renewables covered by wood in this scenario is projected to decrease to around $40 \%$ in 2020 (e.g., increased sourcing from other renewable sources). All in all, this implies that wood consumption for energy generation would grow from around $346 \mathrm{Mm}^{3}$ in 2010 (3.1 EJ) to $573 \mathrm{Mm}^{3}$ (5 EJ) in 2020 and $752 \mathrm{Mm}^{3}$ (6.6 EJ) by 2030. The largest "consumer" of wood for energy is forecasted to be heat and electricity producers in the form of, e.g., co-firing in large-scale coal plants, large-scale biomass 
plants and mid and small-scale combined heat and power plants. The Report [38] notes that highly efficient combustion units will decrease the amount of wood needed to meet future energy demands and suggests that every increase in combustion efficiency of $1 \%$ could save up to $7.5 \mathrm{Mm}^{3}$ in the EU. It should be noted that revised targets in 2014 shifted the amount of wood needed to meet renewable energy targets in 2030 down somewhat compared to the estimates for 2030 extrapolated by the study (published in 2010).

The EUWood project [39] used the econometric modeling projections produced by Jonsson [37] and the energy demands presented by Steierer [38] to estimate the wood resource balance (WRB) for the EU-27 in 2010, 2020 and 2030. The purpose of a WRB is to compare actual and potential supply with demand for a certain country or group of countries to indicate possible discrepancies (gaps) and to monitor the woody biomass balance for a given year. Overall, results showed that potential demand would overtake potential supply between 2015 and 2020 in the A1 scenario with medium mobilization, in particular due to the rising demand for fuelwood. According to the study, "even if all measures for increased wood mobilization are implemented, wood industry demand and renewable energy targets can hardly be satisfied from domestic sources in 2020" [39] (p. 22). Around 70\% of the total supply estimated for 2010 is expected to come from the forest, whereas 30\% from trees outside the forest and other sources.

The European Forest Sector Outlook Study (EFSOS) II [18] also projects material and energetic demand developments to forecast overall developments in timber and forest product supply and demand in the UNECE region (with the exception of North America, the Caucasus and central Asia, Israel and Russia) between 2010 and 2020 to 2030. The WRB (e.g., as in the EUWood project [39]) is also at the core of the study with demand derived from econometric analysis, extrapolation and policy targets and potential wood supply derived from the EFISCEN model for four scenarios: reference, maximizing biomass carbon, giving priority to biodiversity, and promoting wood energy (to meet EU renewable energy targets). EFSOS II also uses the IPCC scenarios to set its context, but uses the B2 storyline as a baseline. The reference scenario for materials is based on the Global Forest Sector Model (a partial equilibrium model focusing on forest products) and the reference scenario for energy is based on an extrapolation of the historical fuelwood consumption rate (estimated at 1.5\% per year). This is significantly below both the amount forecasted to meet renewable energy targets in the EU (3.97\% from Steierer [38] and 2.78\% in the B2 scenario projections from Buongiorno, et al. [35]). In the reference scenario, demand for wood is about 20\% higher in 2030 than in 2010, with slower growth from the forest products industry and faster growth for energy [18]. In the scenario in which the EU meets its energy targets, total demand would increase to around $1200 \mathrm{Mm}^{3}$ with wood demand for energy more than doubling in comparison to 2010, and comprising around $60 \%$ of total demand in 2030. In the reference scenario, an increase in exports is expected $\left(43 \mathrm{Mm}^{3}\right)$, whereas the EU would become a net importer in the energy scenario. It should be noted that the gap between expected supply and demand increases in all future scenarios. In particular, a high gap of $162 \mathrm{Mm}^{3}$ is expected in the biodiversity scenario. This additional demand would probably have to be met by increased imports [18].

\section{Materials and Methods}

To assess the expected global and EU-27 demands for timber until 2030, projections from the literature are drawn on and adapted to fit the scope of this study. In this way, both global and EU consumption "scenarios" are generated and compared to reference value ranges derived directly from O'Brien and Bringezu [31]. These reference value ranges [31] describe an indicative and ambitious "safe operating space" scenario that halts all land use change in 2020 (based on the rationale of preventing further biodiversity loss made by UNEP [7] and Bringezu, et al. [40] connected to the 
related aim of halting the expansion of global cropland by 2020) ${ }^{4}$ and limits harvesting of timber to forest available for wood supply at a rate of $80 \%$ of Net Annual Increment (as an indicative assumption for sustainable appropriation, in need of further research [29]). Total sustainable supply capacity is divided by global population forecasts to generate a reference value range for sustainable consumption based on an equitable per capita global resource distribution following the concept of "fair shares", in light of the Sustainable Development Goals and the 2002 New Delhi Declaration, especially regarding equitable distribution. It should be noted that this sustainability corridor was presented in $\mathrm{O}^{\prime}$ Brien and Bringezu [31] as an indicative estimation to highlight the results of preliminary estimates, raise valid questions about metrics for sustainable consumption, initiate a discussion, and call for future research to this end.

\subsection{Global Consumption Patterns}

Expected trends for global consumption patterns were based on the two studies described above $[19,35]$. The analysis was complemented by data from FAOSTAT ${ }^{6}$ as well as regional forest sector outlook studies for demand developments in the Asia-Pacific, North America, Africa and Latin America, all forecasting an increased demand for timber in the future.

As regards the data presented in Buongiorno, et al. [35], this article derived a linear trend to estimate the consumption levels between the years given in the study (2006 and 2030) for each scenario. The FAO report [19] presents industrial roundwood estimates for 2005, 2020 and 2030 and fuelwood data for 2005 and 2030. For this article, the level of consumption in 2020 for fuelwood was derived based on the annual increase for the production of bioenergy (Mtoe) given in FAO [19] combined with the volumes given for $1970\left(2 \mathrm{Gm}^{3}\right), 2005\left(2.6 \mathrm{Gm}^{3}\right)$ and $2030\left(3.8 \mathrm{Gm}^{3}\right)$. Linear trends are assumed for the years between 2010 and 2030 .

The starting basis of the estimates in the studies $[19,35]$ uses different statistics for the past. In particular, the differences in historical values are due to different methods for forecasting fuelwood demand. Using interpolation, the FAO report [19] presents data well above other key FAO sources for fuelwood production and consumption. For comparative purposes, a very simple extrapolation was thus performed on FAOSTAT fuelwood and industrial roundwood production data. This is possible because at the global level, global production equals global consumption of primary timber. A linear extrapolation of the trends of the last 50 years was extended until 2030 to serve as a reference for the other scenarios.

To be able to compare consumption projections for "raw timber" (without bark) with trees growing in the forest (with bark) and the sustainable reference value ranges derived from O'Brien and Bringezu [31], consumption requirements were converted into a felling volume using the conversion value of 1.15 for global forests (based on the FAO Global Forest Resources Assessment Report [44]). To compare global and EU-27 trends, derived timber demand was divided by expected population. Population projections are based on medium variant estimates from the UN [45] for the global perspective and Eurostat for the EU perspective.

4 Note, this is "safe operating space scenario" is more ambitious than but in keeping with the aim of the European Union to support efforts to "halt global forest cover loss by 2030 at the latest and to reduce gross tropical deforestation by at least $50 \%$ by 2020 compared to current levels" [41] (p. 5). It is also more ambitious than the planetary boundary for forest cover change suggested by [42], which is related primarily to the climate impacts of forest cover change and not the biodiversity impacts.

5 This is a set of seven principles adopted by the International Law Association related to sustainable development. The principles were developed due to a concern over "the growing economic and social inequalities between and within States" [43] and the "need for a comprehensive international law perspective on integration of social, economic, financial and environmental objectives and activities" [43]. The second principle addresses equity and the eradication of poverty, including inter- and intra-generational equity.

6 www.fao.org/faostat/. 


\subsection{EU-27 Consumption Patterns}

Estimating future consumption of primary timber is more challenging for the EU than for the world. At the regional level, annual demand is no longer equivalent to annual extraction due to trade, and the challenge is thus distinguishing regional recycling flows from primary flows. While a number of studies have forecasted EU demand for timber products, the challenge for this study is estimating how much of this demand is expected to be met by primary timber from the forest (woody biomass). In order to estimate total primary raw wood demand in the EU, this article relied on the literature sources described above $[18,35,37-39]$ to forecast the magnitude of expected change. The total primary raw timber consumption of the EU-27 was estimated to be $473 \mathrm{Mm}^{3}$ o.b. in 2010 [30]. This is based on economy-wide material flows analysis assessing both timber flows (accounting for trade of around 100 commodities, imports-exports) and domestic removals (harvest within the EU) using standard conversion values to derive primary raw timber volumes [30]. To project how this estimated volume might develop in the future, it was assumed that primary timber consumption grows at the same rate as overarching timber demand (considering the demand for wood for both products and energy) given by the literature. This is a simplistic assumption in the interests of transparency to develop a first comparison of possible future demand pathways with sustainable supply limits but may not represent the most realistic or optimistic assumptions (e.g., the authors strongly promote meeting a greater share of timber demand with secondary sources (re-used and recycled) in the future). It should also be noted that this method thus overestimates the primary timber demand growth compared to the EUWood and EFSOS II assumptions related to increasing levels of demand met by secondary sources. The method should be improved in the future with more in-depth and comprehensive modeling and scenario assumptions. From the literature, three scenarios were distinguished for this article:

- High growth + RES: Scenario A1 for products and meeting the RES Directive targets for fuel. This scenario is based on the EUWood project [39]. It should be noted that energy wood volumes are based on the literature estimates, which calculated volumes needed for 2030 before revised targets were established in 2014. This implies that lower volumes of wood energy than depicted here may be needed to meet targets, thus indicating a potential overestimation.

- Moderate growth + RES: Scenario B2 for products and meeting the RES Directive targets for fuel. This scenario is based on estimates derived from EFSOS II [18]. It should be noted that these differ somewhat from estimates based on the EUWood project as regards products (estimates between studies for meeting renewable energy targets differ by just $1 \mathrm{M}^{3}$ in 2030). EFSOS II has a lower product demand in the B2 scenario due to revised estimates for paper consumption (reflecting a decreasing trend for graphic paper due to competition with electronic media; it should be noted that this trend is actually more pronounced than estimated, potentially leading to even lower levels of demand for products and more opportunity for energy wood).

- Moderate growth, no RES: Scenario B2 for products and continuation of past trends for fuelwood (extrapolation of $1.5 \%$ per year). This scenario is based on the reference scenario from EFSOS II [18].

In other words, in the EUWood project [39] total demand for solid wood equivalents grows from around $800 \mathrm{Mm}^{3}$ in 2010 to $1100 \mathrm{Mm}^{3}$ in 2020 and $1370 \mathrm{Mm}^{3}$ in 2030 in the IPCC A1 scenario for products and a scenario meeting renewable energy targets for energy. This means that demand grows by $37 \%$ between 2010 and 2020 and by $71 \%$ between 2010 and 2030. This percent change was applied to the total primary consumption estimated for the EU-27 in 2010 (in other words the $473 \mathrm{Mm}^{3}$ estimated by O'Brien and Bringezu [30]). It should be noted that the scenarios from EFSOS II [18] were modified based on the country data to depict the results of the four scenarios for the EU-27 (without Malta and Romania).

\section{Results}

Global results depict a demand for primary raw timber of between around 4.2 and $7.2 \mathrm{Gm}^{3}$ in 2030 (Figure 1). A comparison with the FAOSTAT extrapolated trend reveals that global consumption 
is expected to increase at a higher rate than in the last 50 years. At the global level, the difference between the A1 world and B2 world is distinctive, with the A1 scenario (which is characterized by high growth) showing a tremendous increase in the consumption of wood, which may not be the most plausible expectation for future developments.

In comparison to the sustainable supply range developed by O'Brien and Bringezu [31] the A2 and B2 global scenarios based on Buongiorno, et al. [35] are within or quite close to the upper threshold of the sustainable supply range until 2030. The scenario based on the A1 world with high economic growth and fuelwood demand quickly exceeds the sustainable supply range beyond 2010 (e.g., it exceeds the upper boundary by around 30\% in 2030). The scenarios based on FAO data [19], with high assumptions regarding fuelwood, reveal that the target space was already exceeded in 2010 and that this gap would continue to grow significantly until 2050. In 2030, the upper boundary of the sustainable supply range would be surpassed by around 65\% according to those projections [19]. The simple extrapolation showing a continuation of global trends from the last 50 years based on FAOSTAT data would just exceed the upper threshold of the sustainable supply range in 2030. Altogether, all long-term developments show an overshoot of the global sustainable supply reference range.

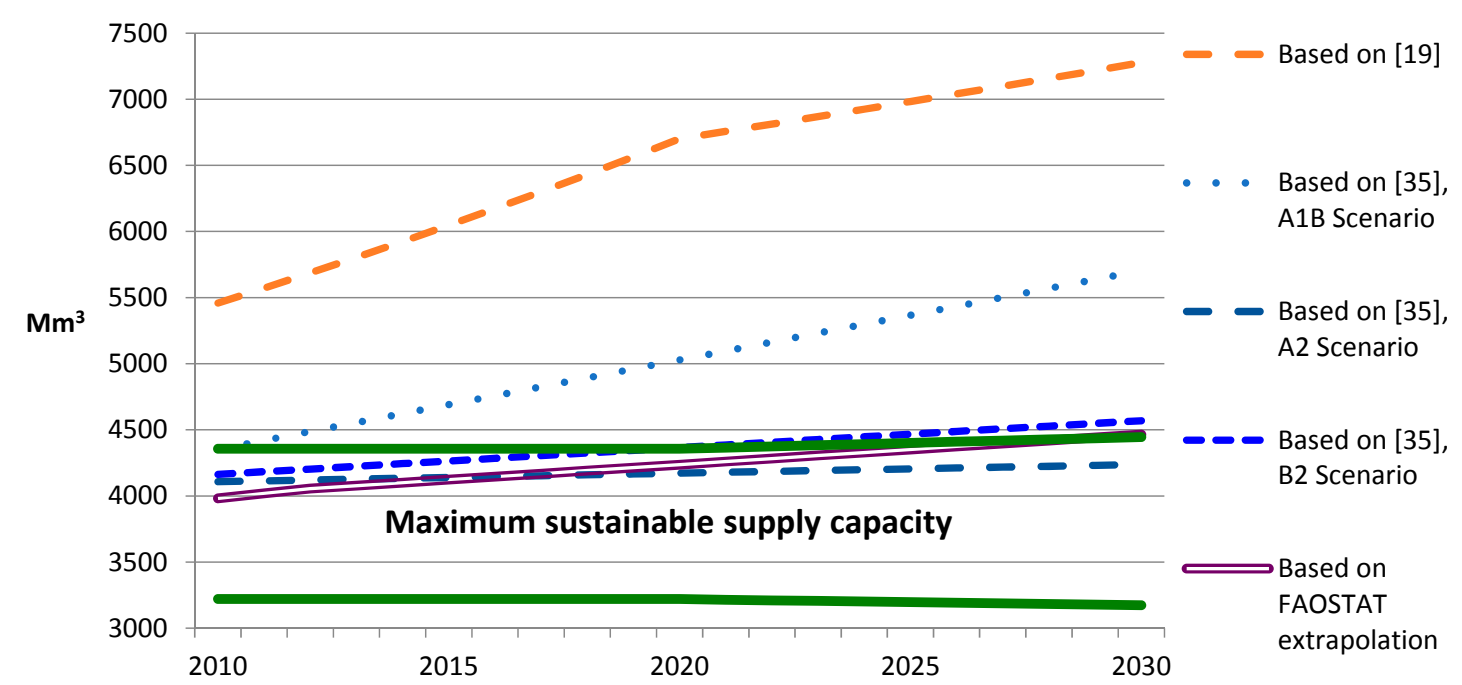

Figure 1. Global consumption scenarios compared to the global forest sustainable supply capacity range of primary timber based on different sources, 2010-2030 Note: Future estimates depict the direction of change based on literature source $[19,35]$ and an extrapolation of past trends from FAOSTAT. Linear annual development is assumed based on data from single points in time. For indicative purposes, the sustainable supply range [31] is extended back to 2010. This is based on a constant space for the period between 2010 and 2020 (e.g., ranging between 3220 and $4360 \mathrm{Mm}^{3}$ ), which encompasses the realistic potential ranges using $80 \%$ and $90 \%$ of NAI in 2010 [31].

Figure 2 depicts results for the EU consumption scenarios compared to the EU sustainable supply range. In the year 2030, the EU would require between around $570 \mathrm{Mm}^{3}$ and $800 \mathrm{Mm}^{3}$ of primary timber to meet demands depending on the scenario (noting in comparison that the total demand for products and energy in the wood resource balance method (i.e., including secondary sources) was estimated by the EUWood project [39] at $1372 \mathrm{Mm}^{3}$ in their A1 scenario for products + meeting renewable energy targets and $1280 \mathrm{Mm}^{3}$ in their B2 scenario for products + meeting renewable energy targets; EFSOS II [18] estimated $989 \mathrm{Mm}^{3}$ in their reference scenario and $1234 \mathrm{Mm}^{3}$ in their promoting wood energy scenario in 2030). Figure 2 shows that in the moderate growth scenario, around $140 \mathrm{Mm}^{3}$ more primary timber would be needed to meet renewable energy targets in comparison to the moderate scenario without reaching RES targets. Around 60\% of demand in 2030 is comprised of fuelwood in the scenarios to meet RES targets and around 50\% of demand is comprised of fuelwood in the scenario without reaching RES targets. As compared to the sustainable supply range, Figure 2 reveals that 
consumption levels will most likely stay below the sustainable supply capacity of EU forests between 2010 and into the 2020s. In the scenarios to meet renewable energy targets, the upper boundary of the sustainable supply range is surpassed in 2024 in the high economic growth scenario and in 2030 in the moderate economic growth scenario. Again, it should be emphasized that primary demand growth may be overestimated, and that meeting higher levels of demand with secondary sources would change these dynamics, with potential implications for the interpretation of the moderate growth scenario, which overshoots the maximum sustainability threshold only at the end of the period. In the scenario with moderate growth and no meeting of renewable energy targets, EU consumption levels stay below or within the sustainable supply range. Altogether, the results imply that to meet renewable energy targets over the long term, the EU would become more dependent on imports and/or require much higher levels of mobilization in domestic forests, which could lead to overuse related to both forest degradation and forest loss. Dependence on increased imports may have similar negative effects if not controlled within a wider framework of sustainable resource management and equitable distribution, with a high concern in particular for raising biodiversity risks (considering in particular that the planetary boundary for biodiversity loss is estimated to have already been surpassed [42,46]). Alternatively, lower levels of primary timber demand for products (e.g., due to increased secondary sources and/or reduced demand due to e.g., paper substitution) could make more space for energy wood in the future.

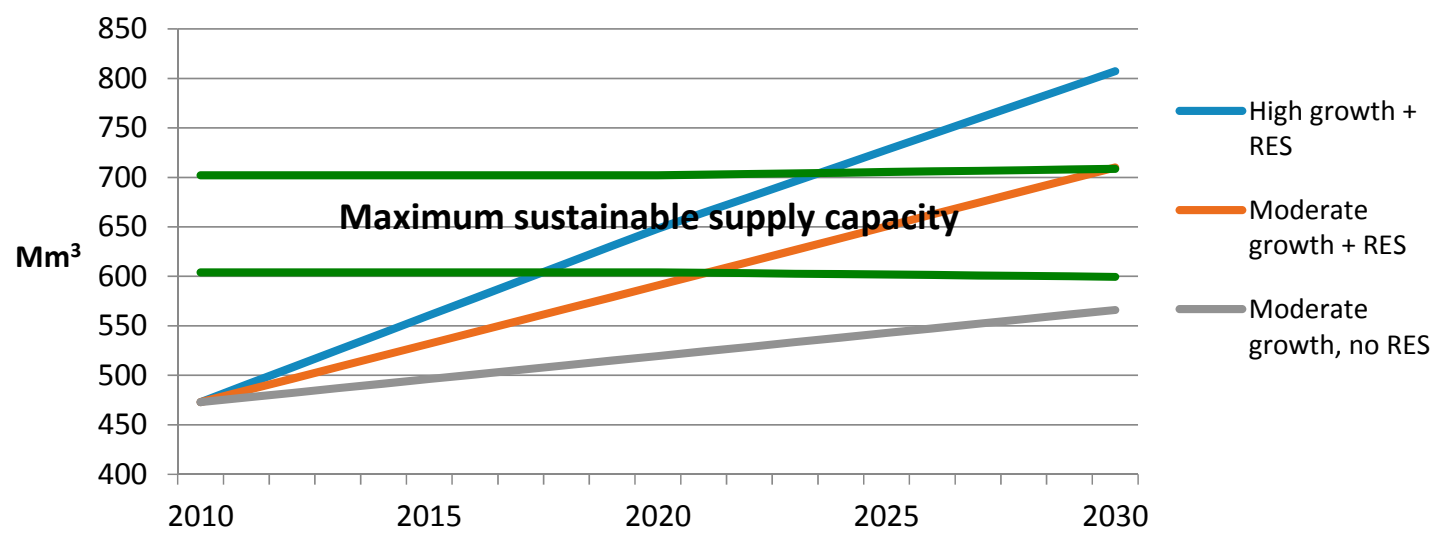

Figure 2. EU consumption scenarios compared to the EU forest sustainable supply capacity range, 2010-2030. Note: Consumption data are based on literature sources [18,39], noting that primary timber demand may be overestimated due to simplified assumptions. For indicative purposes, the sustainable supply range is extended back to 2010. This is based on a constant space for the period between 2010 and 2020 (e.g., ranging between around 600 and $700 \mathrm{Mm}^{3}$ ), which encompasses the realistic potential estimate using $80 \%$ of Net Annual Increment for 2010 [31].

Figure 3 compares global and EU per capita consumption levels estimated in the scenarios. It reveals significantly higher per capita consumption levels for the EU than the global average. EU consumption is 2 times higher than global average consumption comparing the lowest scenario estimates for both the EU and world in 2030 (in other words the moderate economic growth scenario (B2) in both cases, but without achievement of renewable energy targets in the EU). A comparison of the highest scenario estimates for both the EU and world reveals that EU consumption is 1.8 times higher than the global average (e.g., high economic growth and meeting renewable energy targets in the EU compared to trends based on FAO [19] at the global level). Comparing trends within the IPCC scenarios reveals that in the A1 case (high economic growth), EU consumption is 2.3 times higher than the global average, whereas in the B2 case (moderate economic growth), EU consumption is 2.5 times higher than the global average (based on meeting renewable energy targets in the EU in both cases). This indicates that expected EU consumption levels, in particular to meet renewable energy targets, lead to highly disproportionate consumption patterns, which are between 1.8 and 2.5 times higher than the expected average consumption levels on a global basis in 2030. 


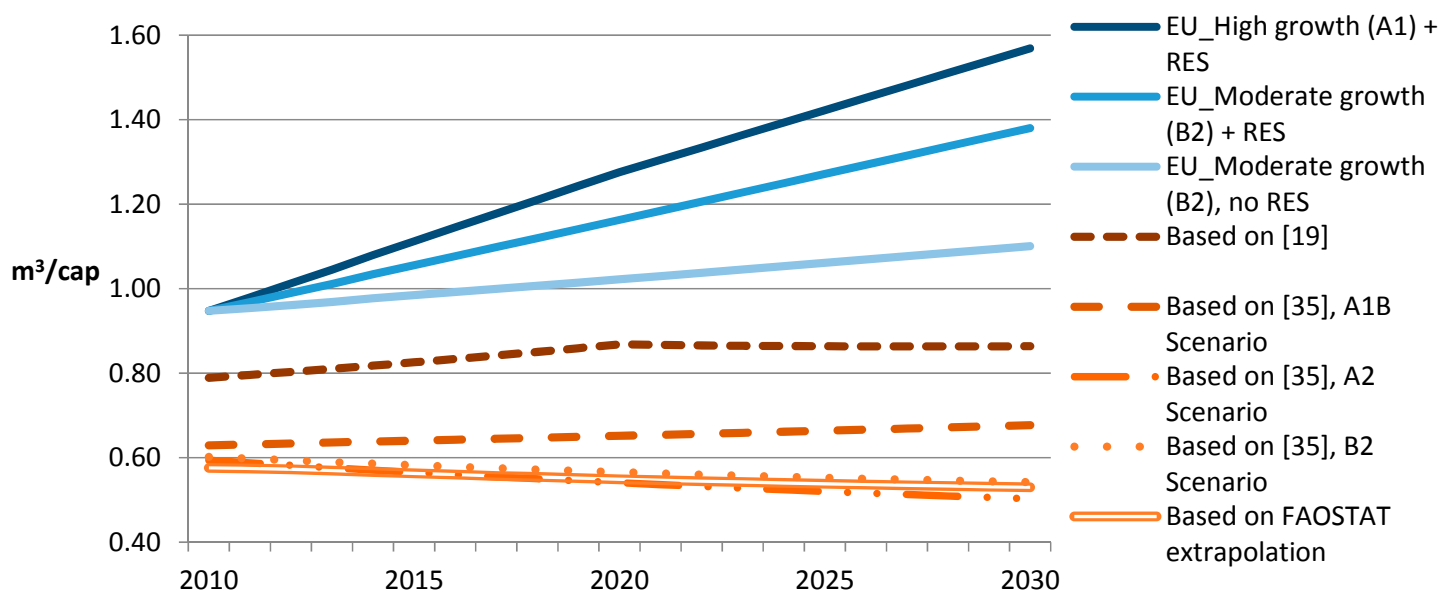

Figure 3. Scenarios of global and EU per capita consumption of primary timber under different assumptions regarding economic growth and fuelwood use, 2010-2050. Note: based on literature sources $[18,19,35,39]$.

Figure 4 depicts per capita consumption scenarios for the EU-27 from 2002 until 2030 compared to the EU and global reference value ranges. It reveals that EU consumption levels will likely stay below the EU reference value range between 2002 and 2020 for all scenarios, but that it has already surpassed the global per capita reference value range significantly. In 2030, the scenario with high economic growth and meeting renewable energy targets would lead to an EU consumption level that would exceed the upper threshold of the EU reference value range by around $15 \%$ and would be nearly 3 times higher than the upper threshold of the global reference value range. The scenario with moderate economic growth and meeting renewable energy targets would lead to an EU consumption level just over the upper threshold of the EU reference value range and nearly 2.6 times higher than the upper threshold of the global reference value range in 2030. Without meeting renewable energy targets and with moderate economic growth, the consumption of EU timber could stay below the EU reference value range in 2030 (it would cross the lower threshold of the reference value range in 2032), but would still be more than 2 times higher than the upper threshold of the global reference value range. This raises serious concerns about an import strategy in the future.

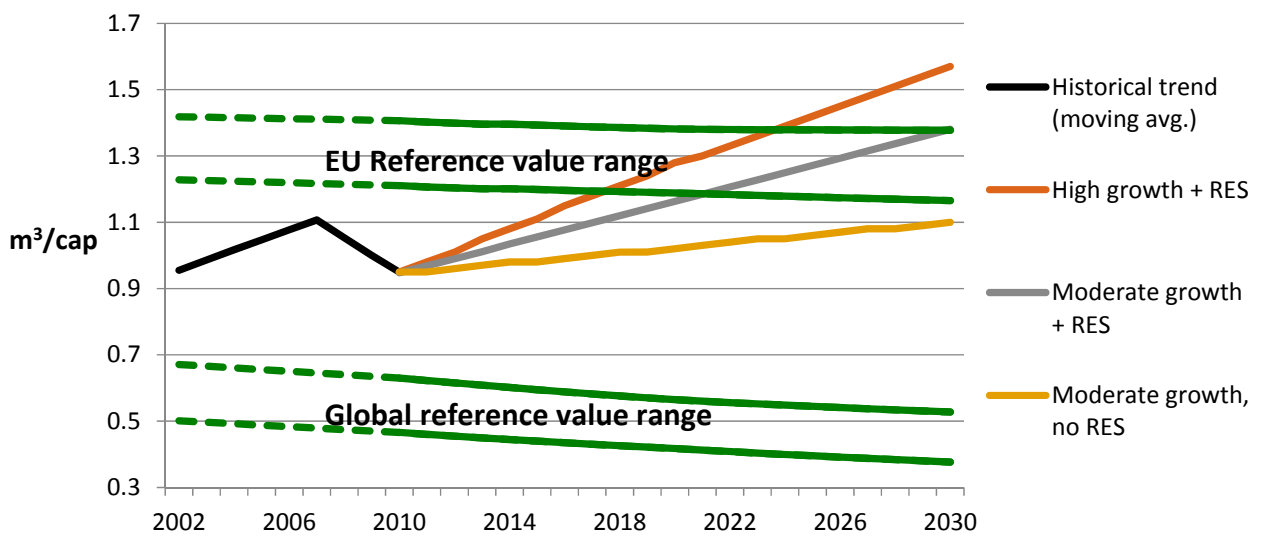

Figure 4. EU consumption levels of primary timber compared to global and EU reference value ranges for sustainable forest supply capacities, 2002-2030. Note: The EU and global reference value ranges are visualized in an indicative way back to 2002 for comparative purposes. This is based simply on an extension of trends. Future EU consumption projections are based on the trends given in literature sources $[18,35]$, noting that primary timber demand may be overestimated due to simplified assumptions. Past EU consumption trends are based on O'Brien and Bringezu [30]. 


\section{Discussion}

Meeting around a 40\% share of renewable energy targets in the EU with timber in 2020 and beyond would increase pressure on global land use with potential impacts on climate change and biodiversity. Results show that meeting renewable energy targets would cause total EU primary timber demand between 2010 and 2030 to increase by around 55 to $70 \%$ (while a total increase of $20 \%$ could be expected in the moderate growth scenario without meeting renewable targets). This increase implies that the EU would exceed its own sustainable supply capacity between 2024 and 2030, potentially making the EU import dependent (to maintain sustainable forest management practices "at home"). In 2030, total EU consumption would be just over to up to around 15\% higher than the upper threshold of the EU reference value range and around 160 to $200 \%$ higher than the upper threshold of the global reference value range. It would thus contribute to the global overshoot of a safe operating space for forest use [31] calculated in the global high growth scenarios. Specifically, two of the global scenarios already showed an overshoot of around 30 to 65\% of the upper sustainable supply boundary, making an import strategy particularly questionable. Somewhat lower targets for energy wood as well as a slow down in product demand growth could ease pressures and make it possible for the EU moderate demand growth scenario to stay within a territorial EU sustainable supply range. This would imply the need for policies that promote sustainable harvesting and timber mobilization within the EU to meet those demands, in order to mitigate the risks associated with shifting production and harvesting abroad. However, such a moderate growth scenario would still be above the global reference value range, raising the question of which reference value range is appropriate for the EU to use as an orientation [31].

Projected consumption levels within the EU are also shown to be highly disproportionate compared to the global average. Average EU consumption would exceed average global consumption levels by a factor of 1.8 to 2.6 in scenarios meeting renewable energy targets under comparable economic developments (e.g., A1 and B2 overarching storylines). In light of the "principle of equity" e.g., in the 2002 New Delhi Declaration [43], such a development would raise risks of contributing to inter- and intra-generational inequity. Depending on how timber is sourced, it may also contribute to hindering the right to fair access of global resources (e.g., in cases of "land grabbing" for plantation establishment and forestry [47]).

Results presented here present a culmination of findings from in a "series" of articles [30,31]. In sum, they point to the need for developing a systemic monitoring of the forest and forest-based sectors including an accounting of timber flows underlined by indicators (like the forest footprint) and sustainability benchmarks (like reference values—and eventually targets—for sustainable supply capacities from forests at different spatial dimensions). This article has highlighted the importance of taking the future perspective into consideration in order to develop smart policies for both timber and forest use in keeping with sustainability considerations. Research is needed to this end, with this article presenting first steps towards a conceptual framework and approach, which must be underpinned by more reliable data as well as methodological robustness in the future.

For example, at the global level, scenarios were based on two sources [19,35]. However, these scenarios showed high differences in the historical levels of consumption for fuelwood (due to different calculation methods) and the level of projected industrial roundwood in the future. This difference is due to different modeling and projection approaches, relying on economic modeling [35] versus an aggregation of expected trends in different regions of the world from forest sector outlook studies [19] (performed together with the FAO and regional experts) based on key drivers of change (regarding demography, economy and policies, in particular energy policies in Europe). This gap points to the need to improve methods and approaches for projecting timber demand, perhaps using a combination of bottom-up trends and top-down modeling, while also taking structural shifts occurring in the forest industry into account [25], in particular as concerns bioenergy [36] and the potentially growing bioeconomy. This relates to the need to better understand processes and trends on the supply side, in particular on better data for timber stemming from plantations [48] as well as 
on forest management, use and relation to environmental challenges such as climate change [4] and biodiversity loss [49].

As regards the EU demand scenarios, strengthened methods are needed to account for primary timber consumption. Most literature sources include projections for consumption based on demand, regardless of whether this expected demand level shall come from primary raw timber or recycling flows. In order to make comparisons to the forest and the sustainable supply capacity, primary flows are needed, including for imports and exports, making also global trends regarding trade of re-used wood products an area for future research. The projections in this article are based on replicating trends given in literature sources and research is needed to develop a methodology and modeling scenarios to specifically address the questions posed in this article. In the future, expert judgment could be one approach to better distinguish primary and secondary sources for different types of flows. It should be noted that as the focus is on primary timber in the projections presented by this article, the total consumption of "timber equivalents" could be much higher in the safe operating space scenario if, e.g., more recycling flows are used. This also highlights the importance of innovation in the re-use and recycling of timber in the future (e.g., such as in cascading use [50-53]) in order to reduce the demand for primary timber. Increased use of secondary sources would mean more products can be offered within the bounds of the safe operating space.

\section{Conclusions}

The findings of this article support the literature pointing to potentially exacerbated environmental, as well as social ${ }^{7}$, problems associated with rapidly and significantly rising demands for timber. In particular, this article has shown that the growing use of timber for energy purposes in the EU imposes the risk of significantly exceeding the estimated "fair shares" of safe operating space for global timber consumption [31]. This points to a high risk of problem shifting and the urgent need for better data, improved accounting and strengthened monitoring across multiple scales of analysis and over time. For policy makers, this implies the need to increase monitoring efforts. There is also an urgent need to shift toward new forms of governance [56] that recognize ecological limits and aim to regulate within them [46]. To this end, a safe operating space for forest use should be defined in a more robust manner-with research needed to strengthen the data basis as well as to investigate the socio-political legitimacy of the safe operating space concept towards targets in the future. Policy makers may continue to increase support for innovation in sustainable forest management, across value chains and in business model development (e.g., towards re-use, recycling and cascades) in order to promote both sustainable production and consumption practices in a way that supports economic competitiveness and respects ecological limits.

Acknowledgments: This article is based on part of the dissertation thesis "Timber consumption and sustainable forest use: Assessing the EU's current and expected consumption of global timber in relation to the global capacity for sustainable supply" published by Kassel University Press in 2016 and supported by the Wuppertal Institute for Climate, Environment and Energy. Kassel University also provided the funding for publishing this article open access.

Author Contributions: Meghan O'Brien prepared the article including research, assessment, and writing. Stefan Bringezu provided support across all phases and supervised, edited, and commented on the article.

Conflicts of Interest: The authors declare no conflict of interest.

7 Not only related to equitable distribution of limited resources, but also to challenges such as land grabbing related to hunger, poverty, and inequality $[54,55]$. 


\section{References}

1. EU. Directive 2009/28/EC on the Promotion of the Use of Energy from Renewable Sources an Demanding and Subsequently Repealing Directives 2001/77/EC and 2003/30/EC; EU: Brussels, Belgium, 2009; Volume 140, pp. 16-62.

2. Eurostat. Statistics Explained: Energy from Renewable Sources, version 17.06.2014; Eurostat: Luxembourg, 2014.

3. Schulze, E.D.; Körner, C.; Law, B.E.; Haberl, H.; Luyssaert, S. Large-scale bioenergy is neither sustainable nor greenhouse gas neutral. Glob. Chang. Biol. Bioenergy 2012, 4, 611-616. [CrossRef]

4. Haberl, H.; Schultze, E.-D.; Körner, C.; Law, B.E.; Holtsmark, B.; Luyssaert, S. Response: Complexities of sustainable forest use. Glob. Chang. Biol. Bioenergy 2013, 5, 1-2. [CrossRef]

5. Agostini, A.; Giuntoli, J.; Boulamanti, A. Carbon Accounting of Forest Bioenergy; Marelli, L., Ed.; European Union Joint Research Centre: Ispra, Italy, 2013.

6. Gibson, L.; Lee, T.M.; Koh, L.P.; Brook, B.W.; Gardner, T.A.; Barlow, J.; Peres, C.A.; Bradshaw, C.J.A.; Laurance, W.F.; Lovejoy, T.E.; et al. Primary forests are irreplaceable for sustaining tropical biodiversity. Nature 2011, 478, 378-381. [CrossRef] [PubMed]

7. UNEP. Assessing Global Land Use: Balancing Consumption with Sustainable Supply; A Report of the Working Group on Land and Soils of the International Resource Panel; UNEP: Nairobi, Kenya, 2014.

8. Smeets, E.; Faaij, A. Bioenergy production potentials from forestry to 2050. Clim. Chang. 2007, 81, 353-390. [CrossRef]

9. Anttila, P.; Karjalainen, T.; Asikainen, A. Global Potential of Modern Fuelwood; Finnish Forest Research Institute: Helsinki, Finland, 2009.

10. Karjalainen, T.; Asikainen, A.; Ilavsky, J.; Zamboni, R.; Hotari, K.-E.; Röser, D. Estimation of Energy Wood Potential in Europe; Working Paper of the Finnish Forest Research Institute 6; Finnish Forest Research Institute: Helsinki, Finland, 2004.

11. Ericsson, K.; Nilsson, L.J. Assessment of the potential biomass supply in Europe using a resource-Focused approach. Biomass Bioenergy 2006, 30, 1-15. [CrossRef]

12. Alakangas, E.; Heikkinen, A.; Lensu, T.; Vesterinen, P. Biomass Fuel Trade in Europe; Report of the EUBIONET II Project; VTT Technical Research Centre of Finland: Espoo, Finland, 2007.

13. Asikainen, A.; Liiri, H.; Peltola, S.; Karjalainen, T.; Laitila, J. Forest Energy Potential in Europe (EU 27); Metla Working Papers 69; Finnish Forest Research Institute: Helsinki, Finland, 2008.

14. Verkerk, P.J.; Anttila, P.; Eggers, J.; Lindner, M.; Asikainen, A. The realisable potential supply of woody biomass from forests in the European Union. For. Ecol. Manag. 2011, 261, 2007-2015. [CrossRef]

15. Hennenberg, K.; Böttcher, H.; Wiegmann, K.; Forsell, N.; Korosuo, A.; Havlík, P.; Valin, H.; Lauri, P.; Gusti, M.; Kindermann, G.; et al. Study on Impacts on Resource Efficiency of Future EU Demand for Bioenergy -Task 2: Analysis of Impacts of Biomass Production on Natural Resources and the Global Environment; European Commission: Brussels, Belgium, 2014.

16. Moffat, A.; Nisbet, T.; Nicoll, B. Environmental Effects of Stump and Root Harvesting; Research Note; 2011. Available online: http://www.forestry.gov.uk/pdf/FCRN009.pdf/\$FILE/FCRN009.pdf (accessed on 22 November 2017).

17. Vanhala, P.; Repo, A.; Liski, J. Forest bioenergy at the cost of carbon sequestration? Curr. Opin. Environ. Sustain. 2013, 5, 41-46. [CrossRef]

18. UNECE; FAO; UN. The European Forest Sector Outlook Study II: 2010-2030; United Nations: Geneva, Switzerland, 2012.

19. FAO. State of the World's Forests 2009; Food and Agricultural Organization of the United Nations: Rome, Italy, 2009.

20. Burger, J.A. Management effects on growth, production and sustainability of managed forest ecosystems: Past trends and future directions. For. Ecol. Manag. 2009, 258, 2335-2346. [CrossRef]

21. Nasi, R.; Frost, P.G.H. Sustainable forest management in the tropics: Is everything in order but the patient still dying? Ecol. Soc. 2009, 14, 40. [CrossRef]

22. Warman, R.D. Global wood production from natural forests has peaked. Biodivers. Conserv. 2014, 23, 1063-1078. [CrossRef]

23. Payn, T.; Carnus, J.M.; Freer-Smith, P.; Kimberley, M.; Kollert, W.; Liu, S.; Orazio, C.; Rodriguez, L.; Silva, L.N.; Wingfield, M.J. Changes in planted forests and future global implications. For. Ecol. Manag. 2015, 352, 57-67. [CrossRef] 
24. Cubbage, F.; Mac Donagh, P.; Sawinski, J.; Rubilar, R.; Donoso, P.; Ferreira, A.; Hoeflich, V.; Olmos, V.V.; Ferreira, G.; Balmeilli, G.; et al. Timber investment returns for selected plantations and native forests in South America and the Southern United States. New For. 2007, 33, 237-255. [CrossRef]

25. Hurmekoski, E.; Hetemäki, L. Studying the Future of the Forest Sector: Review and Implications for Long-Term Outlook Studies. For. Policy Econ. 2013, 34, 17-29. [CrossRef]

26. Opschoor, J.B.; Weterings, R. Environmental Utilisation Space: An Introduction. Tijdschrift Voor Milieukunde 1994, 9, 198-205.

27. Bund für Umwelt- und Naturschutz Deutschland (BUND); Misereor (Eds.) Zukunftsfähiges Deutschland: Ein Beitrag zu Einer Global Nachhaltigen Entwicklung [Sustainable Germany in a Globalized World: Toward Global Sustainable Development]; Birkäuser Verlag: Basel, Switzerland; Bonn, Germany; Berlin, Germany, 1996.

28. UN (United Nations). Agenda 21. In Proceedings of the United Nations Conference on Environment \& Development, Rio De Janerio, Brazil, 3-4 June 1992.

29. O'Brien, M. Timber Consumption and Sustainable Forest Use: Assessing the EU's Current and Expected Consumption of Global Timber in Relation to the Global Capacity for Sustainable Supply; Kassel University Press: Kassel, Germany, 2016.

30. O'Brien, M.; Bringezu, S. European timber consumption: Developing a method to account for timber flows and the EU's global forest footprint. Ecol. Econ.. Forthcoming, accepted with minor revisions.

31. O'Brien, M.; Bringezu, S. What Is a Sustainable Level of Timber Consumption in the EU: Toward Global and EU Benchmarks for Sustainable Forest Use. Sustainability 2017, 9, 812. [CrossRef]

32. EREP. Manifesto and Policy Recommendations of the European Resource Efficiency Platform; European Commission: Brussels, Belgium, 2014.

33. Tukker, A.; Bulavskaya, T.; Giljum, S.; de Koning, A.; Lutter, S.; Simas, M.S.; Stadler, K.; Wood, R. The Global Resource Footprint of Nations-Carbon, Water, Land, and Materials Embodied in Trade and Final Consumption Calculated with EXIOBASE 2.1; The Netherlands Organisation for Applied Scientific Research: Delft, The Netherlands; Leiden University: Leiden, The Netherlands; Vienna University of Economics and Business: Vienna, Austria; Norwegian University of Science and Technology: Trondheim, Norway, 2014.

34. Giljum, S.; Lutter, S.; Bruckner, M.; Aparcana, S. State-of-Play of National Consumption Based Indicators: A Review and Evaluation of Available Methods and Data to Calculate Footprint-Type (Consumption-Based) Indicators for Materials, Water, Land and Carbon; Sustainable Europe Research Institute: Vienna, Austria, 2013.

35. Buongiorno, J.; Zhu, S.; Raunikar, R.; Prestemon, J. Outlook to 2060 for World Forest and Forest Industries; A Technical Document Supporting the Forest Service 2010 RPA Assessment; USDA: Ashville, AL, USA, 2012.

36. Raunikar, R.; Buongiorno, J.; Turner, J.A.; Zhu, S. Global outlook for wood and forests with the bioenergy demand implied by scenarios of the Intergovernmental Panel on Climate Change. For. Policy Econ. 2010, 12, 48-56. [CrossRef]

37. Jonsson, R. Econometric Modeling and Projections of Wood Products Demand, Supply and Trade in Europe; Geneva Timber and Forest Discussion Paper 59; United Nations Publication: Geneva, Switzerland, 2012.

38. Steierer, F. Energy Use; EUwood: Hamburg, Germany, 2010.

39. Mantau, U.; Saal, U.; Prins, K.; Steierer, F.; Lindner, M.; Verkerk, H.; Eggers, J.; Leek, N.; Oldenburger, J.; Asikainen, A.; et al. Real Potential for Changes in Growth and Use of EU Forests; EUwood: Hamburg, Germany, 2010.

40. Bringezu, S.; O’Brien, M.; Schütz, H. Beyond biofuels: Assessing global land use for domestic consumption of biomass: A conceptual and empirical contribution to sustainable management of global resources. Land Use Policy 2012, 1, 224-232. [CrossRef]

41. Council of the European Union. Addressing the Challenges of Deforestation and Forest Degradation to Tackle Climate Change and Biodiversity Loss; Council of the European Union: Brussels, Belgium, 2008.

42. Steffen, W.; Richardson, K.; Rockström, J.; Cornell, S.E.; Fetzer, I.; Bennett, E.M.; Biggs, R.; Carpenter, S.R.; de Vries, W.; de Wit, C.A.; et al. Planetary boundaries: Guiding human development on a changing planet. Science 2015, 374. [CrossRef] [PubMed]

43. ILA. New Delhi declaration of principles of international law relating to sustainable development. In Proceedings of the 70th Conference of the International Law Association, New Delhi, India, 2-6 April 2002.

44. FAO. Global Forest Resources Assessment 2010; FAO Forestry Paper 163; FAO: Rome, Italy, 2010.

45. UN. World Population Prospects: The 2012 Revision. 2012. Available online: www.unpopulation.org (accessed on 15 March 2014). 
46. Rockström, J.; Steffen, W.; Noone, K.; Persson, Å.; Chapin, F.S., III; Lambin, E.F.; Lenton, T.M.; Scheffer, M.; Folke, C.; Schellnhuber, H.J.; et al. A safe operating space for humanity. Nature 2009, 461, 472-475.

47. Nolte, K.; Chamberlain, W.; Giger, M. International Land Deals for Agriculture_Fresh Insights from the Land Matrix: Analytical Report II; Centre for Development and Environment, University of Bern: Bern, Germany; Centre de Coopération Internationale en Recherche Agronomique Pour le Développement: Montpellier, France; German Institute of Global and Area Studies: Hamburg, Germany; University of Pretoria: Pretoria, South Africa; Bern Open Publishing: Bern, Germany, 2016.

48. Jürgensen, C.; Kollert, W.; Lebedys, A. Assessment of Industrial Roundwood Production from Planted Forests; FAO Planted Forests and Trees Working Paper FP/48/E; FAO: Rome, Italy, 2014.

49. Ceballos, G.; Ehrlich, P.R.; Dirzo, R. Biological annihilation via the ongoing sixth mass extinction signaled by vertebrate population losses and declines. Proc. Natl. Acad. Sci. USA 2017, 114, E6089-E6096. [CrossRef] [PubMed]

50. Dornburg, V.; Faaij, A. Costs and $\mathrm{CO}_{2}$-emission reduction of biomass cascading: Methodological aspects and case study of SRF poplar. Clim. Chang. 2005, 71, 373-408. [CrossRef]

51. Keegan, D.; Kretschmer, B.; Elbersen, B.; Panoutsou, C. Cascading use: A systematic approach to biomass beyond the energy sector. Biofuels Bioprod. Biorefin. 2013, 7, 193-206. [CrossRef]

52. Essel, R.; Carus, M. Increasing resource efficiency by cascading use of biomass. RURAL21 2014, 48, 28-29.

53. Vis, M.; Mantau, U.; Allen, B. (Eds.) Study on the Optimised Cascading Use of Wood; Final Report, No 394/PP/ENT/RCH/14/7689; EU: Brussels, Belgium, 2016.

54. UN. A New Global Partnership: Eradicate Poverty And Transform Economies Through Sustainable Development; The Report of the High-Level Panel of Eminent Persons on the Post-2015 Development Agenda; UN: New York, NY, USA, 2013.

55. UNEP. Policy Coherence of the Sustainable Development Goals: A Natural Resource Perspective; A Report of the International Resource Panel; UNEP: Nairobi, Kenya, 2015.

56. Howlett, M.; Rayner, J. Design Principles for Policy Mixes: Cohesion and Coherence in "New Governance Arrangements". Policy Soc. 2007, 26, 1-18. [CrossRef]

(C) 2017 by the authors. Licensee MDPI, Basel, Switzerland. This article is an open access article distributed under the terms and conditions of the Creative Commons Attribution (CC BY) license (http://creativecommons.org/licenses/by/4.0/). 